Studia Anglica Posnaniensia 46/1, 2010

doi: 10.2478/v10121-009-0027-0

\title{
TEACHING PUNCTUATION IN EARLY MODERN ENGLAND ${ }^{1}$
}

\author{
ALICIA RODRÍGUEZ-ÁLVAREZ
}

\author{
University of Las Palmas de Gran Canaria
}

\begin{abstract}
Much has been written on the punctuation practice of late sixteenth- and seventeenth-century English writers in order to work out the ultimate function of marks of punctuation. The main point of discussion has almost ever been whether punctuation indicated syntactic relationships or represented speech pauses either to give emphasis in oral delivery or just to be able to breathe. The focus of this paper, however, is the theory rather than the practice, in particular, the set of rules and conventions used by schoolmasters to guide students in their use of stops. Thus, textbooks used at the time to teach reading and writing will constitute our main sources of information to achieve the following aims: (i) to offer a classification of the different marks of punctuation described, (ii) to establish the functions schoolbooks assigned to punctuation marks in general, and (iii) to assess the importance schoolmasters gave to pointing. The results of this study - which follows the works by Ong (1944) and Salmon $(1962,1988)$ - will contribute to shed light on the ever-lasting debate on the principles guiding Early Modern English punctuation usage.
\end{abstract}

1. The scope of this paper within earlier discussions on Renaissance punctuation theory

The use of marks of punctuation in the Renaissance has been the source of inspiration of many scholarly discussions which have attempted to discern the function of punctuation marks, the key issue being whether they could be considered aiding tools for oral delivery or marks to indicate syntactic relationships (Baron 2001). In order to answer this question, the punctuation in the works of Ben Jonson, William Shakespeare, and other contemporary authors as well as

1 This paper is a contribution to the research project HUM2007-60725/FILO sponsored by the Spanish Ministry of Science and Education. This grant is hereby gratefully acknowledged. 
their printer's practice have been subject to scrutiny in a number of works (e.g. Maxwell 1953, Graham-White 1982, Simpson 1911 and Howard 1930) which have mainly concluded that there is a correspondence between punctuation marks and performance indications. ${ }^{2}$ The results of these studies, however important they are, do not settle the problem, since the analyses are, in a way, corpus-biased due to the oral nature of the works studied, and as Jenkinson (1926: 53) puts it, "did a writer of Essays or History think always of his work being read aloud?"

Other authors, such as Fries (1925), Ong (1944) and Salmon (1988), have focused on the theoretical accounts and rules taught in the late 16th and early 17 th centuries reaching different conclusions. The importance of Fries's work lies in his belief that the practice of Renaissance punctuation somehow followed a general system of rules contained in contemporary handbooks:

\begin{abstract}
Although the practice of the times might easily not strictly conform to the theory of the grammarians (and very probably in any case only loosely conformed) it seems unlikely that that practice could have been unconsciously based upon another principle differing so fundamentally from that expressed in contemporary grammars (...) (Fries 1925: 81).
\end{abstract}

Indeed, authors, as subject to the educational system of the time, could not be ignorant of the punctuation rules taught and practised in schools, and we logically assume that points used by playwrights should have a sense for somebody else apart from the author. This idea guided Fries in his attempt to find general common principles behind the use of Renaissance punctuation and led him to propose a syntactic and structural basis of punctuation marks.

Walter J. Ong, in his 1944 paper, refutes Fries's (1925) ideas by showing the classical and medieval sources of Renaissance treatments of punctuation and their influence upon them. His work defends the prevailing status of breathing, rather than syntax, in punctuation, as is made clear in the following quote:

\begin{abstract}
From the evidence in texts which between 1582 and 1640 treat of punctuation, there is little doubt that there survived not only (...) the terminology of the earlier systems $(\ldots)$, but also a recognition of the primacy of breathing as a determinant of punctuation. (Ong 1944: 355)
\end{abstract}

Fries and Ong, however, used very limited corpora for their analyses, five and seven works respectively, which did not prove the best ones to support their conclusions. In this way, for example, out of the seven accounts examined by Ong, only those by Mulcaster (1582), Heywood (1612), Jonson (1692) and

2 Alden (1924) puts into doubt that punctuation of Shakespeare's printers was guided just by elocutionary reasons. 
Daines (1640) unmistakably and primarily relate signs of punctuation to breathing pauses. Nevertheless, their contributions helped to reconsider the value of pointing in Renaissance education.

Salmon's (1988) thorough survey about the theoretical accounts on punctuation from the 16th to the 18th century in England constitutes the most definite contribution to English punctuation theory so far. Not only did the number of accounts considered increased in Salmon's (1988) ground-breaking work but also the topics discussed, which range from the relevance of these studies for contemporary linguistics, the different systems of punctuation used, the classifications of points, their function, their sources, etc.

The present paper, inspired by the works of Fries (1925), Ong (1944) and Salmon (1988), aims to find common patterns in the punctuation marks established by Early Modern English schoolmasters and the functions assigned to them. In order to do so, I have compiled a relevant corpus of sixteenth- and seventeenth-century handbooks for school use. Salmon (1988: 289-290) had already included schoolmasters as a professional group with a special interest in punctuation, an interest that manifests itself in the amount of manuals dealing with pointing. My ultimate intention is to show that punctuations marks were part of the curriculum of Renaissance students, and future playwrights. They learnt their function and use in handbooks written by schoolmasters who considered them essential for a successful composition, unambiguous interpretations and skilled reading. The general conclusions drawn from this analysis will help to have a better understanding of punctuation in Renaissance England.

\section{The corpus}

As the focus of interest of this paper is the teaching of punctuation in early stages of instruction, the corpus selected consists of thirty handbooks composed for school use during the late 16th and 17th centuries. Titles and prefaces to books have proved very useful tools to make this selection as they are excellent indicators of authors' professional endeavours and intentions. Hence, information regarding the aim of the work, the audience addressed to or the professional qualifications of the authors of the corpus reports that most of them are longexperienced schoolmasters in different parts of England who have devised their works to help other colleagues when teaching young students reading and writing skills, two abilities and two words which will be present in all these works.

The resulting list of handbooks studied includes the thirty titles listed in the references as "primary sources", many of which, as far as I know, have never been studied in this respect. 


\section{A typology of marks of punctuation: A general consensus}

Renaissance schoolmasters agreed on the necessity of studying punctuation for writing and reading properly and they took interest in describing and explaining the different signs of punctuation. Moreover, a detailed examination of the discussions on punctuation reveals a relative consistency in the selection and number of marks described, and in the criteria adopted to classify them. In this way, most of them either just distinguish six or seven stops or they mark them off as primary stops or points used in the sentence, to distinguish them from other characters. In other words, according to most schoolmasters studied, those punctuation marks considered of primary importance for the composition and reading of a text are the comma, the colon, the full stop, the note of admiration and the note of interrogation; some of them also include either the semicolon ${ }^{3}$ or the parenthesis, and other ones both. All these marks are grouped under the generic term "points", "stops" and less frequently "pauses", although in the 16th century we still find the term "distinction" as a witness to Early Modern English teachers' indebtedness to classical models (Ong 1944: 350). The following table ordered chronologically illustrates the selection of marks in each author as well as the few variant terms:

Table 1. Punctuation marks in sixteenth- and seventeenth-century textbooks: generic and specific names.

\begin{tabular}{l|c|c|c|c|c|c}
\hline & $;$ & $:$ & $\cdot$ & $!$ & $?$ & $(\quad)$ \\
\hline \multicolumn{7}{c}{ Hart $^{4}(1569)$ : Distinction or pointing } \\
\hline comma & - & colon & periode & $\begin{array}{c}\text { marke of the } \\
\text { admirative }\end{array}$ & $\begin{array}{c}\text { marke of the } \\
\text { interrogative }\end{array}$ & parenthesis \\
\hline \multicolumn{7}{c}{ Mulcaster (1582): Distinction } \\
\hline comma & - & colon & period & - & interrogation & parenthesis \\
\hline \multicolumn{7}{c}{ Clement (1587): Distinction and pointing of sentences } \\
\hline
\end{tabular}

The semicolon was only widely adopted in England in the late 16th century (Parkes 1992: 86, 216-217; Bruthiaux 1995; Lennard 1995: 67), which accounts for its absence in the sixteenth-century handbooks consulted. Even Lewis (1674: 3), Hogarth (1649: 48) and Hill (1697: 101) refer to it as a late incorporation.

4 Hart also includes square brackets to insert commentaries in translations, although he does not name them, just draws them. 


\begin{tabular}{|c|c|c|c|c|c|c|}
\hline & & & point & & & \\
\hline \multicolumn{7}{|c|}{ Coote (1596): Points or states in writing } \\
\hline comma & - & colon & period & - & interrogation & parenthesis \\
\hline \multicolumn{7}{|c|}{ Daines $^{5}$ (1640): Stops, points or pauses } \\
\hline comma & $\begin{array}{l}\text { comma- } \\
\text { colon }\end{array}$ & colon & period & $\begin{array}{c}\text { exclamation } \\
\text { point }\end{array}$ & $\begin{array}{c}\text { interrogation } \\
\text { point }\end{array}$ & parenthesis \\
\hline \multicolumn{7}{|c|}{ Hodges (1644): Points or stops } \\
\hline comma & semi-colon & colon & period & $\begin{array}{c}\text { admiration } \\
\text { point } \\
\end{array}$ & $\begin{array}{c}\text { interrogation } \\
\text { point }\end{array}$ & - \\
\hline \multicolumn{7}{|c|}{ Hodges (1653): Points or stops } \\
\hline comma & - & colon & period & $\begin{array}{c}\text { admiration } \\
\text { point }\end{array}$ & $\begin{array}{c}\text { interrogation } \\
\text { point }\end{array}$ & parenthesis \\
\hline \multicolumn{7}{|c|}{ Wharton (1654): Points } \\
\hline comma & - & colon & period & ecphonesis & erotesis & parenthesis \\
\hline \multicolumn{7}{|c|}{ Adis (1660?): Stops or points } \\
\hline comma & semi-colon & colon & period & admiration & $\begin{array}{c}\text { interrogation } \\
\text { note }\end{array}$ & parenthesis \\
\hline \multicolumn{7}{|c|}{ Price (1665): Points } \\
\hline comma & semicolon & colon & $\begin{array}{l}\text { period } \\
/ \text { full } \\
\text { point } \\
\end{array}$ & $\begin{array}{l}\text { note of admi- } \\
\text { ration }\end{array}$ & $\begin{array}{c}\text { note of inter- } \\
\text { rogation }\end{array}$ & parenthesis \\
\hline \multicolumn{7}{|c|}{ Price (1668): Points } \\
\hline comma & semicolon & colon & $\begin{array}{l}\text { period } \\
\text { or full } \\
\text { point } \\
\end{array}$ & $\begin{array}{l}\text { note of admi- } \\
\text { ration }\end{array}$ & $\begin{array}{c}\text { note of inter- } \\
\text { rogation }\end{array}$ & parenthesis \\
\hline \multicolumn{7}{|c|}{ Lye (1671): Points, pauses or stops } \\
\hline comma & semi-colon & colon & $\begin{array}{l}\text { period } \\
\text { or full } \\
\text { stop } \\
\end{array}$ & $\begin{array}{l}\text { exclamation } \\
\text { or note of } \\
\text { admiration }\end{array}$ & interrogation & parenthesis \\
\hline \multicolumn{7}{|c|}{ Lewis (1674): Points } \\
\hline comma & semicolon & colon & period & - & - & - \\
\hline \multicolumn{7}{|c|}{ Walker $(1676)^{6}$ : Points } \\
\hline comma & - & colon & period & $\begin{array}{c}\text { note of admi- } \\
\text { ration }\end{array}$ & $\begin{array}{c}\text { note of inter- } \\
\text { rogation }\end{array}$ & - \\
\hline
\end{tabular}

5 Daines also includes in his list the apostrophe, although with reservations "For pause of time, it hath none belonging to it, and therefore not so properly inserted among the points, or stops. But onely as I thought it convenient, by reason of the Character; which is necessary to be knowne and distinguished" (Daines 1640: 72-73).

$6 \quad$ Walker's (1676: 41) comment: "And with these are usually taught a Parenthesis (...) and a Parathesis" reveals his disagreement with this inclusion. 


\begin{tabular}{|c|c|c|c|c|c|c|}
\hline \multicolumn{7}{|c|}{ A Treatise of Stops (1680): Stops, points or pauses } \\
\hline comma & semi-colon & colon & period & $\begin{array}{c}\text { ecphonesis or } \\
\text { exclamation }\end{array}$ & $\begin{array}{c}\text { erotesis or } \\
\text { interrogation }\end{array}$ & - \\
\hline \multicolumn{7}{|c|}{ Strong (1681): Points or stops } \\
\hline comma & semi-colon & colon & $\begin{array}{l}\text { period } \\
\text { or full } \\
\text { stop }\end{array}$ & admiration & interrogation & parenthesis \\
\hline \multicolumn{7}{|c|}{ Smith (1683): Points or notes } \\
\hline comma & semi-colon & colon & period & $\begin{array}{l}\text { note of ex- } \\
\text { clamation or } \\
\text { admiration }\end{array}$ & $\begin{array}{l}\text { note of inter- } \\
\text { rogation }\end{array}$ & parenthesis \\
\hline \multicolumn{7}{|c|}{ Fox (1683): Points } \\
\hline comma & semi-colon & colon & period & admiration & interrogation & parenthesis \\
\hline \multicolumn{7}{|c|}{ Mather $^{7}$ (1685): Points } \\
\hline comma & semicolon & colon & period & admiration & interrogation & parenthesis \\
\hline \multicolumn{7}{|c|}{ Miege (1688): Stops } \\
\hline comma & semi-colon & colon & full stop & admiration & interrogation & - \\
\hline \multicolumn{7}{|c|}{ Hogarth (1689): Points } \\
\hline comma & semicolon & colon & $\begin{array}{c}\text { period } \\
\text { or full } \\
\text { point }\end{array}$ & admiration & interrogation & - \\
\hline \multicolumn{7}{|c|}{ Browne (1692): Stops or points } \\
\hline comma & semi-colon & colon & period & $\begin{array}{c}\text { note of admi- } \\
\text { ration }\end{array}$ & $\begin{array}{c}\text { note of inter- } \\
\text { rogation }\end{array}$ & parenthesis \\
\hline \multicolumn{7}{|c|}{ Hawkins (1692): Points, pauses } \\
\hline comma & semicolon & colon & period & $\begin{array}{l}\text { note of admi- } \\
\text { ration }\end{array}$ & $\begin{array}{l}\text { interrogation } \\
\text { or interroga- } \\
\text { tive point }\end{array}$ & parenthesis \\
\hline \multicolumn{7}{|c|}{ The Writing Scholar's Companion (1695): Points or stops } \\
\hline comma & semicolon & colon & $\begin{array}{l}\text { period } \\
\text { or full } \\
\text { stop }\end{array}$ & admiration & interrogation & parenthesis \\
\hline \multicolumn{7}{|c|}{ Hill (1696): Points or stops } \\
\hline comma & semicolon & colon & period & admiration & interrogation & - \\
\hline \multicolumn{7}{|c|}{ Brown (1700): Stops or points } \\
\hline comma & semi-colon & colon & period & $\begin{array}{c}\text { note of admi- } \\
\text { ration }\end{array}$ & $\begin{array}{c}\text { note of inter- } \\
\text { rogation }\end{array}$ & - \\
\hline
\end{tabular}

$7 \quad$ Mather (1685) also talks about hyphens (-). 
Out of these twenty five authors, Mather (1685), Hart (1569), Clement (1587), Coote (1596), Walker (1676), Smith (1683), Hodges (1644, 1653) and Adis (1660?) do not mention any other mark in their discussions on punctuation. The other ones, though, include in their reviews of pointing other signs, although they feel they are intended for different purposes and therefore refer to them with a different name and present them separately. In this way, Wharton (1654: $84,87)$ calls them "secundary points"; Miege talks about "other distinctions" (1688: 122) and "figures" (1688: 123); Lewis labels them "figurative points" (1674: 2); "notes" is the term used by Browne (1692: 12), Hill (1696: 102), the author of $A$ Treatise of Stops (1680: 8) and Hogarth (1689: 54), although Browne adds the adjective "accidental" in his 1700 revision (1700: 15), and Hogarth also uses the name "characters" (1689: 54); finally, Hawkins (1692: 102) introduces them as "other marks".

This terminological diversity seems to reflect the schoolmasters' uneasiness about these marks of punctuation which are generally thought to serve different purposes. Mulcaster (1582: 149), Lye (1671: 139), Price (1665: 36; 1668: 40) and the author of The Writing Scholar's Companion (1695: 116) consider them points that affect words, and accordingly the latter calls them "points relating to single words" (The Writing Scholar's Companion 1695: 116) in contrast to the punctuation marks pertaining sentences, namely, the primary points described in the chart above. Secondary points include the apostrophe, the dieresis and the hyphen, among others. But most authors just present a wide array of marks such as the caret, the asterisk, the index, the obelisk, the double comma, the eclipsis, etc. without any sort of arrangement.

As these marks are out of the scope of this study, I will just concentrate on the general function of the so-called primary points about which, as the comparison of the handbooks shows, there is a general consensus regarding the number of punctuation marks to be studied by schoolboys as well as the terms to refer to them.

$8 \quad$ Finally there is a group of authors who discuss all of them without any distinction such as Matlock (1685), Preston (1673), Johnson (1665), and finally Care (1687), who distinguishes between a group of marks that affects the word and another one that affects the sentence, but here he includes a miscellany of notes. The number of handbooks that treat notes, characters and punctuation marks as a monolithic group is so insignificant that we may conclude that authors were aware of the different nature and function of a full stop, for example, and a caret or a pointing hand in a text. 
4. The importance of teaching punctuation: Reading and writing properly ${ }^{9}$

If we look through English Renaissance grammars and books on writing and reading, we will realize that a high number of them include a section devoted to stops which some authors claim to be based on "observation for true pointing" (Hogarth 1689: 42) because "being so variously discoursed of by Authors of several Ages, I shall not much concern my self with what the Ancients have said, but consider it as it is now most generally used" (Hogarth 1689: 44). Authors even highlight the necessity of a correct observation of points in the title of these chapters; Lye, for example, calls his chapter on punctuation "Of Points, pauses, or Stops, used in writing and Printing" and he adds "which are carefully to be observed in reading" (Lye 1671: 139). Likewise, Strong insists on this idea in the title of his chapter "Concerning Points or Stops used in Sentences, which reading Scholars ought to be acquainted with" (1681: 124), and other authors begin their discussions on punctuation with a brief reference to the attention we must pay to points in order to become good writers and skilled readers (Preston 1673?: 11; A Treatise of Stops, Points, or Pauses 1680: A2).

Short justifications become longer explanations for the inclusion of such chapters in other treatises whose authors claim the great importance of a proper use of marks of punctuation. In this sense, for example, Hill says that:

(...) that which among the Learned is accounted the most necessary thing in writing, is the Art of True Pointing; and because many are ignorant therein, (by which means their Letter may bear false constructions, and so disappoint their Expectations) I shall give some brief Directions to that purpose (Hill 1696: 101).

Smith, on his part, goes a little bit further and advances some of the reasons why punctuation is considered so important by Renaissance schoolmasters:

Forasmuch as the Points or Notes used by the Learned in distinguishing writing (...) are not the least part of Orthography, or of the right manner of writing: the ignorance whereof is frequently not only an obstacle to the discerning of the elegancy in writing, but likewise to the perceiving of the writers scope, drift and sense: It will therefore no be impertinent here to add a few lines in explanation; thereof (Smith 1683: 245).

In fact, a proper understanding of the writer's intention is the main reason cited by most schoolmasters to support the teaching of punctuation. ${ }^{10}$ They argue that

\footnotetext{
9 Among a number of questions that scholarly works have neglected, Lennard (1995: 65) includes the importance assigned to punctuation by Renaissance authors.

10 Salmon (1988: 289) had already put forward that the so-called "syntactic-semantic function" of punctuation prevails in most handbooks.
} 
misunderstandings may arise if stops are not used or they are used wrongly:

And indeed, these Points (...) are so necessary, that many times for want of them the Sense may be mistaken, or the true meaning of it perverted, even to the prejudice of the Writer (...) (Hill 1696: 103-104).

Furthermore, the lack of punctuation marks does not only affect the misinterpretation of a writer's words; Hogarth warns against those cases that can affect a man's reputation or even his inheritance (1689: 43), and surely readers became more attentive to these than to his examples quoted from classical literature (1689: 42). Similarly, Hodges observes that "Great care ought to be had in writing, for the due observing of points; for, the neglect thereof will pervert the sens" (1653: 42), besides, he notices the wrong punctuation in the following sentence "My son, if sinners intise thee, consent thou, not refraining thy foot from their way" which should be punctuated like this: "My son, if sinners intise thee, cōsent thou not; refraining thy foot from their way" (1653: 42). More examples are provided by Lye, who also notes that "the neglect, or misplacing the Points is apt much to pervert the sense, and true meaning of a Sentence" (1671: 141); comments of the like can also be found in A Treatise of Stops (1680:7) which even explains fully one of the examples provided by Lye. ${ }^{11}$

Since semantic and syntactic criteria usually go hand by hand, some of these authors' accounts are just guided by syntactic and structural principles in their formulation of rules for pointing (Johnson 1665, Price 1665, Price 1668, Matlock 1685, Lewis 1674), as the following definition of the comma shows:

\begin{abstract}
A Comma is a Note of distinction, between words in the same Sentence, when there follows something depending on what went before; as, I am perswaded, that neither death, nor life, nor angles, nor principalities, nor powers, nor things present, nor things to come, nor height, nor depth, shall be able to separate us from the love of God in Christ Jesus (Price 1665: 37).
\end{abstract}

But even in those discussions where sense distinction and sentence structure prevail, directions for breathing or voice modulations slip in the detailed explanations of each sign. Therefore, authors such as Browne (1692: 11), Care (1687: 58), Hawkins (1692: 101), Walker (1676: 40), Hill (1696, 101-102), Smith (1683), and the author of The Writing Scholar's Companion (1695: 106-107) introduce new elements into the equation: punctuation marks will not only

11 The mispunctuated examples given by Lye are "Prov. 14. 6. A scorner seeketh wisdom, and findeth it, not but knowledg" and "Mat. 7. 24 A wise man built an house upon a Rock, and the flood beat upon it, and it fell, not" which should be "(...) and findeth it not" and "(...) and it fell not", respectively. For a study of the use of mispunctuation in Renaissance literature as a rhetorical device see Kreuzer (1938) and Van den Berg (1995: §11). 
avoid misunderstandings by signalling syntactic structures, they will mark the reader pauses to breathe and intonation patterns. ${ }^{12}$ The author of The Writing Scholar's Companion (1695: 106-116), for example, (i) asserts that "the greatest use of Pointing, is that the sence may be distinguished", but also (ii) indicates the length of pauses for each punctuation sign, (iii) argues that "due Pointing, also assists the Reader to a right Pronunciation, by raising or falling the Voice; according to the Sence, distinguished by the several stops" and (iv) makes extensive use of syntactic explanations in his definitions. Similar combinations of criteria to define and explain punctuation marks can be found in other authors such as Care (1687: 59):

\begin{abstract}
A comma (...) is a note of a short stay, or distinction between words in the same sentence, when yet the Sense is imperfect, to supply which, something follows depending on what went before: And therefore in Reading, the Voice must there be a very little stopt, but the tenor of it still kept up Care (1687: 59).
\end{abstract}

Likewise, the few authors who pointed at breathing as the main justification of stops, used syntactic and semantic principles in their definitions (Miege 1688, Hodges 1653: 42) so that only a limited number of them stuck just to breathing or elocutionary reasons (Coote 1597, Daines 1640, Mather 1685, Hawkins 1692). It is also interesting to note that even some of these authors still admit the importance of punctuation signs as sense distinctions. This is the case of Browne. In the revision of his own method, which had proved successful after seven years of practice, Browne recognizes "some deficiencies which [he] judged necessary to correct" (The Preface). Among the corrections we find the inclusion of a second function of pointing: "to distinguish sense" (1700: 14). Adis (1660?) also considers stops marks for breathing, but at the end of his account, he mentions the importance of "learners to have a perfect understanding" of their reading in order to "make sense of what they read, if sense be written" [italics mine] (1660?: a 3v), where the words understanding and sense stand out as aims of punctuation related to reading and writing skills.

And, in fact, although the great majority of schoolmasters is not consistent in the use of a single criterion when they get to define and explain punctuation marks (see also Lye 1671, Preston 1673, A Treatise of Stops, Points, or Pauses 1680, Strong 1681, Fox 1683, Wharton 1654), most of them, as shown so far,

12 Rodríguez-Álvarez notes that, as early as the 15 th century, the anonymous author of a short tract on reading aloud reconciled the functions assigned by rhetoric and grammar: "(...) in the written medium, marks of punctuation indicate sense units which are uttered with a particular intonation in the discourse" (1998b: 125); he "(...) even warns that pauses made in incorrect locations may puzzle the hearers in two ways: they may link parts of the discourse which are unrelated, or they may separate parts of the discourse which are, indeed, related" (1998b: 124). 
agree on the main aim of punctuation: to make reading and writing comprehensible. ${ }^{13}$ Sense, reading and writing are key words in this story and they may explain this apparent inconsistency, because, what does this inconsistency mean? Is it that we will never be able to discern the ultimate function of punctuation marks in Renaissance handbooks? Seemingly, this was not a problem for Renaissance teachers who thought that semantic, syntactic, elocutionary or breathing reasons justified the existence of punctuation marks. Why are we then so punctilious? Why to speak in mutually exclusive terms when contemporary authors did not do so? ${ }^{14}$ Renaissance schoolmasters, aware or not, made use of the benefits of a multifunctional system of punctuation. In fact as early as the 16th century, Hart (1569), Mulcaster (1582) and Clement (1587) account for the different functions punctuation marks may have depending on the role of that who puts them into practice, that is, a writer or a reader. And this is probably the key question, that is, we do not have to discern whether punctuation marks serve one function or another because both can be compatible and, in any case, it will always depend on the user's role, as Walker (1676: 40) and Care (1687: 58) state in the introduction to their accounts on punctuation: ${ }^{15}$

\footnotetext{
And because a taste at least of this knowledge of Points and Pointing, is highly necessary towards the Scholars both right reading and understanding, and also to his right construing (...), therefore I will here add somewhat of it (Walker 1676: 40).

Due Pointing is very necessary in Writing, to prevent Confusion, and assists the Reader, both as to a right pronunciation, by the raising and falling of the Voice; and also, to the more easy and distinct Apprehension of the Sense (Care 1687: 58).
}

Practically all Renaissance schoolmasters coincided in considering sense and meaning the primary aim of punctuation. Sense will be properly rendered, communicated, and read by means of points which will help reading aloud, reading in silence and writing. Breathing pauses, sense and intonation are not incompatible and that is why most Renaissance schoolmasters gave directions to their students so that they could use, understand and "perform" punctuation marks.

\section{Conclusions}

13 Ong also notes that “( $\ldots)$ the punctuation theory of the time (...) was based on a mixed set of principles" (1944: 359).

14 On the uselessness of applying modern criteria to early marks of punctuation, see Rodríguez-Álvarez (1998a, 1999), Alonso-Almeida (2002), Calle-Martín and MirandaGarcía $(2005,2008)$.

15 Lennard's comment goes in the same direction "the mutually exclusive opposition of the elocutionary and syntactic functions of punctuation is misguided, (...) most if not all punctuation can and does normally function in either mode, or in both" (1995: 68). 
The present survey of Early Modern English handbooks has shown that schoolmasters gave considerable importance to the study of punctuation. Therefore they devoted part of their works to teach some rules for pointing devised to convey sense to the students' reading and writing.

Although some authors put emphasis on syntax and others on pauses and/or voice modulation, in general terms, they agree on the repertory of marks included in their accounts - the comma, the colon, the full stop, the note of admiration and the note of interrogation; the semicolon and the parenthesis being omitted in some of them - and those who deal with other characters distinguish this set as primary points or points related to the sentence. This agreement also extends to the terminology used to refer to the punctuation signs and to the prevailing interest in meaning and sense for proper reading and writing.

They consider points marks of the writer and for the reader. This makes it impossible to impose a rigid system of rules since reading and writing become then both sides of the same coin. They are not excluding terms but key concepts for the formulation of definitions and functions of punctuation marks. Thus, for Early Modern English schoolmasters, punctuation has as its main aim meaning, and as its function, to help readers and writers to convey meaning by means of the different punctuation marks.

\section{REFERENCES}

PRIMARY SOURCES

(pages on punctuation between brackets)

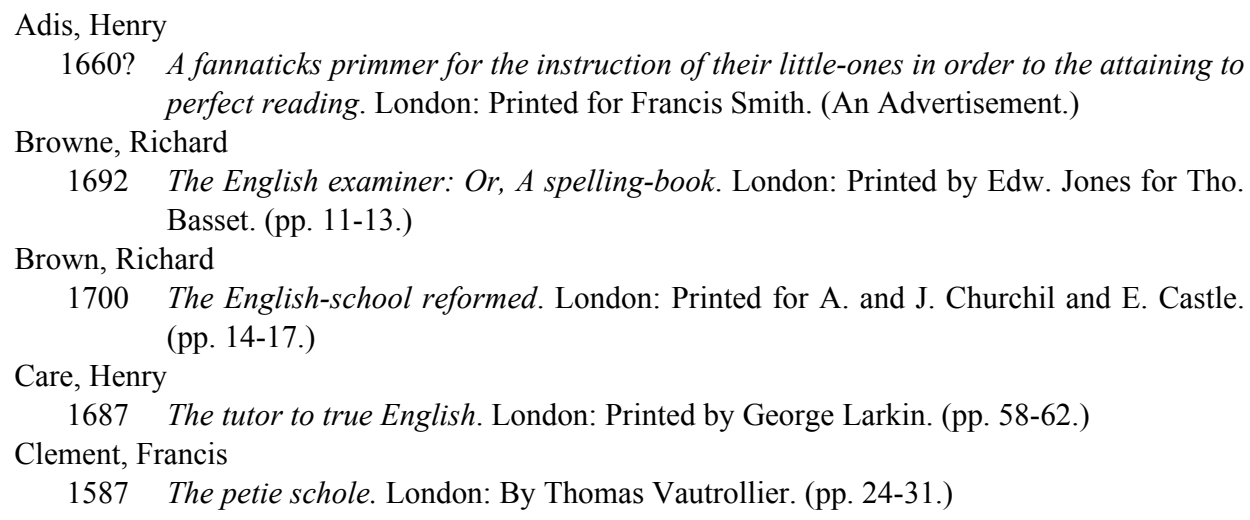


Coote, Edmund

1596 The English schoole-maister. London: Printed by the widow Orwin, for Ralph Iackson, and Robert Dextar. (p. 30.)

Daines, Simon

1640 Orthoepia Anglicana: Or, the first principall part of the English grammar. London: Printed by Robert Young and Richard Badger for the Company of Stationers. (pp. 6975.)

Fox, George

1683 Instructions for right-spelling, and plain directions for reading and writing true English. London: Printed for Benjamin Clark. (pp. 70-71.)

Hart, John

1569 An orthographie conteyning the due order and reason, howe to write or paint thimage of mannes voice, most like to the life or nature. London: By [Henry Denham? for] William Seres. (pp. 40-42.)

Hawkins, John

1692 The English school-master compleated. London: Printed by A. and I. Dawks for the Company of Stationers. (pp. 101-102.)

Hill, John

1696 The young secretary's guide. London: Printed for H. Rhodes. (pp. 101-104.)

Hodges, Richard

1644 The English primrose. London: Printed for Richard Cotes. (pp. N2v- N3.)

1653 Most plain directions for true-writing. London: Printed by W.D. for Rich. Hodges. (pp. 40-42.)

Hogarth, Richard

1689 Thesaurarium trilingue publicum: Being an introduction to English, Latin and Greek. London: Printed by J. L. (pp. 42-55.)

Johnson, Ralph

1665 The scholars guide from the accidence to the university, or short, plain, and easie rules for performing all manner of exercise in the grammar school. London: Printed for Tho. Pierrepont. (pp. 2-3.)

Lewis, Mark

1674. An essay to facilitate the education of youth, by bringing down the rudiments of grammar. London: Printed for Thomas Parkhurst. (pp. 2-4.)

Lye, Thomas

1671 The childs delight. London: Printed for S. Simmons for Tho. Parkhurst. (pp. 139-141.)

Mather, William

1685 The young man's companion, or a very useful manual for youth. London: printed for

Matlock, John Thomas Howkins. (pp. 18-19.)

1685 Fax nova artis scribendi. London: Printed by John Leake. (pp. 20-21.)

Miege, Guy

1688 The English grammar. London: Printed by J. Redmayne. (pp. 122-126.)

Mulcaster, Richard

1582 The first part of the elementarie. London: By Thomas Vautroullier. (pp. 148-153.) Preston, Henry

1673 Brief directions for true-spelling. London: Printed by J. R. (pp. 11-13.) 
Price, Owen

1665 The vocal organ, or a new art of teaching the English orthographie. Oxford: printed by William Hall, for Amos Curteyne. (pp. 36-38.)

Price, Owen

1668 English orthographie or the art of right spelling, reading, pronouncing, and writing all sorts of English words. Oxford: Printed by Henry Hall, for Francis Titon. (pp. 4143.)

Smith, John

1683 The mystery of rhetorick unveil'd. London: Printed for George Eversden. (pp. 245250.)

Strong, Nathaniel

1680 A Treatise of Stops, Points, or Pauses, and of Notes which are used in Writing and in Print. London: Printed for the Authors Use in his School.

1681 England's perfect school-master. London: Printed by J. R. for Benjamin Billingsley. (pp. 124-128.)

Walker, William

1676 Some improvements to the art of teaching. London: printed by J. M. (pp. 40-51.)

Wharton, Jeremiah

1654 The English-grammar, or, the institution of letters, syllables, and words in the English-tongue. London: Printed by William Du-Gard for the autor [sic]. (pp. 84-88.)

The Writing Scholar's Companion

1695 London: printed for the author. (pp. 106-123.)

\section{SECONDARY SOURCES}

Alden, Raymond Macdonald

1924 "The punctuation of Shakespeare's printers", Publications of the Modern Language Association of America 39, 3: 557-580.

Alonso-Almeida, Francisco

2002 "The punctuation practice in a late medieval English medical remedybook", Folia Linguistica Historica 21, 1-2: 207-232.

Baron, Naomi S

2001 "Commas and canaries: The role of punctuation in speech and writing", Language Sciences 23: 15-67.

Bruthiaux, Paul.

1995 "The rise and fall of the semicolon: English punctuation theory and English teaching practice", Applied Linguistics 16, 1: 1-14.

Calle-Martín, Javier - Antonio Miranda-García

2005 "Aspects of punctuation in the Old English Apollonius of Tyre", Folia Linguistica Historica 26, 1-2: 95-113.

2008 "The punctuation system of Elizabethan legal documents: The case of G.U.L. MS Hunter 3 (S.1.3)", The Review of English Studies 59, 240: 356-378.

Fries, Charles C.

1925 "Shakespearian punctuation", University of Michigan Publications in Language and Literature. Studies in Shakespeare, Milton and Donne 1: 67-86. 
Graham-White, Anthony

1982 "Elizabethan punctuation and the actor: Gammer Gurton Needle as a case study", Theatre Journal 34, 1: 96-106.

Howard, Edwin J.

1930 “The printer and Elizabethan punctuation”, Studies in Philology 27: 220-229.

Jenkinson, Hillary

1926 "Notes on the study of English punctuation of the sixteenth century", The Review of English Studies 2, 6: 152-158.

Jucker Anreas H. (ed.)

1995 Historical pragmatics. Amsterdam: John Benjamins.

Kreuzer, James R.

1938 "Some earlier examples of the rhetorical device in Ralph Roister Doister (III.iv.33

ff.)", The Review of English Studies 14, 55: 321-323.

Lennard, John

1995 "Punctuation: And - pragmatics", in: Andreas H. Jucker (ed.), 65-98.

Maxwell, James Coutts

1953 "The punctuation of Macbeth", The Review of English Studies N. S. 4, 16: 356-358.

Ong, Walter J.

1944 "Historical backgrounds of Elizabethan and Jacobean punctuation theory", Publications of the Modern Language Association of America 59, 2: 349-360.

Parkes, Malcolm B.

1992 Pause and effect: An introduction to the history of punctuation in the West. Hants: Scolar Press.

Rodríguez-Álvarez, Alicia

1998a "The role of punctuation in fifteenth-century vernacular deeds", Folia Linguistica Historica 19, 1-2: 27-51.

1998b “A Middle English lesson on reading aloud", Atlantis. Journal of the Spanish Association for Anglo-American Studies 20, 1: 123-128.

1999 "Segmentation of fifteenth-century legal texts", SELIM. Journal of the Spanish Society for Mediaeval English Language and Literature 9: 11-20.

Salmon, Vivian

1988 "English punctuation theory 1500-1800", Anglia 106: 285-314.

Van den Berg, Sara

1995 “Marking his place: Ben Jonson's punctuation”, Early Modern Literary Studies 1, 3: 21-25. (available at: http://purl.oclc.org/emls/01-3/bergjons.html) (Date of access 15 December 2009.) 